\title{
15
}

\section{Integrating social and environmental change in prehistory: A discussion of the role of landscape as a heuristic in defining prehistoric possibilities in northeast Thailand}

\author{
William E. Boyd \\ School of Environmental Science and Management, Southern Cross University, Australia \\ william.boyd@scu.edu.au \\ Nigel Chang \\ School of Anthropology, Archaeology and Sociology, James Cook University, Australia
}

\section{Introduction}

Just as landscape maps memory and declares identity, so too it offers a key to interpreting society ... the land itself, as socially constituted, plays a fundamental role in the ordering of cultural relations ... And as a community merges with its habitus, through the actions and activities of its members, the landscape may become a key reference point for expressions of individual as well as group identity. ... it is now clear that landscape is neither exclusively natural nor totally cultural; it is a mediation between the two and an integral part of Bourdieu's habitus, the routine social practices within which people experience the world around them. Beyond habitus, however, people actively order, transform, identify with and memorialise the landscape by dwelling within it. The environment manifests itself as landscape only when people create and experience space as a complex of places. (Knapp and Ashmore 1999:16, 20-21)

The archaeological study of past societies is an inherently difficult activity. Relying on extremely small samples of the available evidence, often many millennia after the event, archaeologists have the unenviable task of inferring complex relationships and processes for societies whose social, cultural, political and cognitive characteristics are likely to be very different from those of the archaeologists investigating them. Consequently, archaeologists are developing and adopting an increasingly wide range of analytical and conceptual tools 
with which to tackle the task of unravelling past social behaviour and history. While palaeoenvironmental study has frequently been called on, it has been largely to provide an assumed passive background, a stage on which people have enacted their social and cultural activity, or a resource providing the essential energy and materials for a successful society, merely at risk of being degraded by the very societies which rely on that resource. However, there is a growing and vibrant literature that promotes the truism that people and environment are intimately linked. Building on this close relationship, geographers, in particular, recognise landscape as a crucial unifying element, a phenomenon that both recognises and reflects the mutual interactivity of people and their environment. In this paper, we discuss the heuristic of the landscape as a source of evidence in assisting in defining social possibilities in the past. By doing this, we recognise both archaeological and geoarchaeological data as equal sources of data reflecting past social behaviour. We use an example from northeast Thailand - the Neolithic to Iron Age occupation of the upper Mun River valley - to demonstrate the potential that such an integrating approach may have for furthering our understanding of past social behaviour. In particular, we focus on a crucial event towards the end of the Iron Age, in which the choice of a re-patterning of settlement across the landscape, while conventionally being understood as an obligatory response to either environmental degradation or an inevitable socio-political progress, can be better explained as a unique and non-obligatory response to a particular set of socioenvironmental conditions, emerging from a history of evolving social identity intimately associated with the landscape of the previous 2000 years.

\section{Origins of society in northeast Thailand}

The evolution of the human species and subsequent change in social organisation and subsistence practices have long been subjected to explanation based, at least in part, on our relationship to the environment. The clearest example of this is surely the coincidence of the rise of agriculture-based lifestyles and the end of the last Ice Age at a number of locations around the world (e.g. Fagan 2007). In Southeast Asia, for example, Higham and $\mathrm{Lu}(1998)$ have suggested that initial rice agriculture in the middle Yangtze River developed as a result of a worldwide return to colder conditions (the Younger Dryas) that disrupted the otherwise relatively steady warming of the planet following about 12,000 BC. However, it is still common to find archaeologists using environment as a non-interactive background that either directs change in human societies or provides context within which change is constrained. What are not always acknowledged are the complex feedback relationships between humans and their environments. This complexity has been brought into sharp focus recently as modern global warming or climate change is increasingly acknowledged as a reality.

To return briefly to Higham and Lu's (1998) discussion of the origins of rice agriculture, we can see a partial attempt to understand this relationship in prehistory. Essentially, their argument is that as the planet warmed, the inhabitants of the middle Yangtze River valley became increasingly reliant on the wild rice that was abundant in the local swampy environment. As temperatures cooled, rice probably grew less abundantly; an important choice had to be made. Should the people move elsewhere (south?) where wild rice presumably continued to grow abundantly, or remain and adapt their subsistence strategy to other food resources? Or, as Higham and Lu conclude, should they adapt in another way, and invest time and resources into encouraging rice to grow? In a sense, they were changing to remain the same. By making this latter choice, the process of domestication begins, and what was a natural swampy environment became a constructed swampy environment that was, eventually, replicated right across Asia. This process is clearly of huge import for understanding past change in Asia and, just as clearly, is the result of a complex inter- 
relationship between people and environment. Implicit in Higham and Lu's discussion is the construction, and subsequently evolution and maintenance, of new landscapes, key elements in reflecting social behaviour and choice and, in turn, in defining social identity (cf. Knapp and Ashmore 1999).

\section{Archaeology and geography: People, place and landscape}

As Knapp and Ashmore indicate above, there is good reason to consider people and environment as a single entity, expressed, and potentially interpretable, through the concept of landscape. It is landscape, as a heuristic device, that we discuss here. In particular, we suggest that environmental conditions offer not only a backdrop for past human behaviour, but, more importantly, key evidence to model social change through time. In doing so, we acknowledge that concepts of society, environment and especially landscape are difficult and notably 'unstable' (cf. Tilley 1994), and that the inherent mutual interactivity between people and environment - Basso's 'interanimation' (1996) - makes, unlike conventional use of environmental data as social backdrop or resource, a simple cause-and-effect analysis difficult. Social relations are, however, inherently complex, so their interpretation and analysis must also be expected to be complex.

Here we take as a case study our efforts to integrate environmental and archaeological investigations, research questions and interpretations within an archaeological study in the upper Mun River valley of northeast Thailand. Our study centres on the site of Ban Non Wat and associated projects, most of which have been conducted under the extended Origins of the Civilisation of Angkor project driven by Charles Higham, Rachanie Thosarat and Amphan Kijngam (Higham 2002, 2004; Higham et al. 2007). The considerable palaeoenvironmental research that has already been done in the project will form a central part of the following discussions. An important parallel with Higham and Lu's work (1998) is that while we are not looking at the initial development of agriculture, we are looking at the first introduction of an agricultural economy to an apparently previously unfarmed region (Higham 2002).

\section{The challenge: Integrating palaeosocio-environmental processes}

Our specific question is whether we can use an integrated socio-environmental approach to develop a satisfactory explanation of prehistoric conditions. In the context of this case study, the question has been prompted by the need to account for the following broad archaeological observations: there was a long and continuous stable and healthy prehistoric occupation in the Mun River valley; at least during the middle to late Iron Age, there appears to be a major discontinuity in this occupation; there is some evidence of changing social structures over time; new technologies are introduced (bronze and then iron working among others); and the environment has changed, expressed in terms of water, vegetation and sedimentation. The basis for these observations will be discussed below, and they form the basis for a proposed integrated model of change in the region and a strategy for investigating and testing this model. Specifically, we argue that it is important that data from intensive archaeological excavations be extended and integrated with studies focusing on landscape and environment, so as to place Ban Non Wat and other sites more clearly in the wider context of the past social and environmental world(s) of the upper Mun River catchment. This approach may help us to better imagine how the people of Ban Non Wat saw and interacted with this integrated social and environmental world, their landscape (cf. Källén 2004). 


\section{Ban Non Wat and the Origins of the Civilisation of Angkor}

\section{Context}

It is often commented that archaeology in Southeast Asia has but a recent history. However, the pace of research has increased markedly over the past decade or so, particularly reflecting the opening up of China, Burma, Cambodia, Vietnam and Laos to foreign researchers, as well as the growth of cultural heritage and research projects being undertaken by national archaeologists in each country (Higham 2002; Glover and Bellwood 2004; Stark 2006; O'Reilly 2007). The database of excavation and survey has increased to the point that it is increasingly difficult for any one researcher to be familiar with the whole region. One of the many positive outcomes of this situation is that it is now possible (and desirable) to develop detailed regional sequences so that social trajectories in different environments can be compared; one region in which this process is well advanced is the upper Mun River valley in lower northeast Thailand.

An important place in the upper Mun River landscape is the town of Phimai in northeast Thailand, once a provincial northern capital of the Angkorian empire that was based on the northern shores of the Tonle Sap in modern Cambodia, and now a focus for a rich archaeological history (Williams-Hunt 1950; Higham 1977; Welch 1984; Moore 1988a, b; McNeill and Welch 1991; Nitta 1991; O'Reilly 1998, 1999, 2000, 2003). Most recently, a major archaeological project entitled The Origins of the Civilisation of Angkor (hereafter referred to as the Origins project) has examined the prehistoric base from which the Angkorian Empire developed (Higham 2002, 2004; Higham and Thosarat 2005; Higham et al. 2007). The Origins project undertook archaeological excavation and field work at several sites to the northwest of Phimai; the site of Ban Non Wat is the most recent and arguably the most significant. Excavations have also been completed at the sites of Ban Lum Khao (Higham and Thosarat 2005), Noen U-Loke and Non Muang Kao (O’Reilly 1998, 1999; Higham et al. 2007), as well as within the Phimai Prasat (sanctuary) itself (Talbot 2000, 2002).

\section{Archaeological foundations}

At Ban Non Wat, eight seasons of excavation (January 2002 to February 2009) have revealed cemetery and occupation evidence for repeated, possibly continuous, use from at least 4000 years ago (Higham 2002, 2004). Initial pre-metal occupation is followed by Bronze and Iron Age settlement. The upper levels include evidence of Angkorian (late first millennium AD) and later use, with a modern living village being the most recent use of the site. The site is thus far unique in having such a long stratigraphic sequence so intensely investigated; more than 550 burials, for example, representing all the prehistoric periods, offer an unparalleled opportunity to understand social change over time.

Details of the archaeological evidence are discussed below. For now, it is important to note that current work at Ban Non Wat represents the latest stage of archaeological discovery that began with the observations of Williams-Hunt (1950), who first alerted the Englishreading community to the 'moat-and-mound' sites distributed throughout, principally, the Mun and Chi River valleys of northeast Thailand. The defining characteristic of these sites is the presence of moats or, in Williams-Hunt's words, 'irregular earthworks' (Williams-Hunt 1950; Higham and Kijngam 1982), surrounding the central mound. Initial interpretations of these sites stressed the identity of the earthworks as moats, their association with Iron Age pottery and a likely association with developing chiefdoms in the region. Associations with artefacts of Indian origin or inspiration, the introduction of the plough and therefore possible intensification of agriculture, an assumption that some degree of central organisation was required to construct moats, and the ability to organise the production of iron artefacts, 
have all been cited as evidence for the development of chiefdoms, along with the appearance of these 'moated' sites (e.g. Higham 1989). Such interpretations bear closer examination and, as we shall see below, can be questioned. For now, they stand as general background to archaeological knowledge before the Origins project field work began. Importantly, in drawing attention to these sites, Williams-Hunt opened a long-standing discussion of the prehistoric landscape of this region, in which many assumptions and preconceptions were brought to bear on interpreting past human behaviour.

The Mun and Chi valley archaeology is characterised by many large sites, now $3 \mathrm{~m}$ to $5 \mathrm{~m}$ high mounds over several hundred hectares, comprising the remains of substantial and often long-lived settlements, and surrounded by distinctive encircling earthworks and channels commonly known as moats (Boyd 2008). Since the encircling earthworks imply a relationship between hydrological conditions and prehistoric settlement, it is reasonable to assume there was a particular association between environment and society in this region. Environmental examination of these sites and their landscapes (Moore 1988a, b, 1992; Boyd et al. 1999a, b; Boyd and McGrath 2001a, b; McGrath and Boyd 2001; Boyd 2004, 2007, 2008; Boyd and Habberfield-Short 2007; Habberfield-Short and Boyd 2007; McGrath et al. 2008) has progressed to a point where integration with the archaeology is possible (Figure 1).

\begin{tabular}{|c|c|c|c|c|c|c|}
\hline $\begin{array}{l}\text { Calendar } \\
\text { C BC/AD }\end{array}$ & $\begin{array}{l}\text { Palaeo- } \\
\text { geographic } \\
\text { phases }\end{array}$ & $\begin{array}{l}\text { Vegetation } \\
\text { phases and } \\
\text { thresholds }\end{array}$ & $\begin{array}{l}\text { Hydrological } \\
\text { phases and } \\
\text { thresholds }\end{array}$ & Social changes & $\begin{array}{c}\text { Regional } \\
\text { social } \\
\text { influences }\end{array}$ & $\begin{array}{c}\text { Regional } \\
\text { environmental } \\
\text { influences }\end{array}$ \\
\hline $9 \mathrm{AD}$ & \multirow{5}{*}{ Phase 6} & \multirow{4}{*}{$\begin{array}{l}\text { ?modern } \\
\text { conditions }\end{array}$} & \multirow{4}{*}{$\begin{array}{l}\text { ?modern } \\
\text { conditions }\end{array}$} & \multirow{4}{*}{$\begin{array}{l}\text { Centralised state } \\
\text { landscape }\end{array}$} & Angkor & \multirow{9}{*}{$\begin{array}{l}\text { Dry, seasonal } \\
\text { rainfall, } \\
\text { floodplain } \\
\text { sedimentation }\end{array}$} \\
\hline $8 \mathrm{AD}$ & & & & & \multirow{4}{*}{ Zhenla } & \\
\hline $7 \mathrm{AD}$ & & & & & & \\
\hline $6 \mathrm{AD}$ & & & & & & \\
\hline $5 \mathrm{AD}$ & & Rapid change & Rapid change & Rapid change & & \\
\hline $4 \mathrm{AD}$ & \multirow{6}{*}{ Phase 5C } & \multirow{6}{*}{$\begin{array}{l}\text { Phased } \\
\text { landscape } \\
\text { management }\end{array}$} & \multirow{2}{*}{$\begin{array}{l}\text { Construction } \\
\text { engineering }\end{array}$} & \multirow{7}{*}{$\begin{array}{l}\text { Change in focus } \\
\text { on identity, } \\
\text { claim on place, } \\
\text { and social } \\
\text { intensification }\end{array}$} & \multirow{2}{*}{ Funan } & \\
\hline $3 \mathrm{AD}$ & & & & & & \\
\hline $2 \mathrm{AD}$ & & & \multirow{4}{*}{$\begin{array}{l}\text { Adaptive } \\
\text { Engineering }\end{array}$} & & \multirow{4}{*}{$\begin{array}{l}\text { Social } \\
\text { dislocations in } \\
\text { the region }\end{array}$} & \\
\hline $1 \mathrm{AD}$ & & & & & & \\
\hline $1 \mathrm{BC}$ & & & & & & \\
\hline $2 \mathrm{BC}$ & & & & & & \\
\hline $3 \mathrm{BC}$ & \multirow{3}{*}{ Phase 5B } & \multirow{18}{*}{$\begin{array}{l}\text { Early gradual } \\
\text { vegetation } \\
\text { change }\end{array}$} & \multirow{13}{*}{$\begin{array}{l}\text { Settlement } \\
\text { beside rivers, } \\
\text { gradual } \\
\text { hydrological } \\
\text { change }\end{array}$} & & Indianisation? & \\
\hline $4 \mathrm{BC}$ & & & & \multirow{12}{*}{$\begin{array}{l}\text { Internal focus } \\
\text { on identity } \\
\text { and landscape; } \\
\text { mixed economy }\end{array}$} & & \\
\hline $5 \mathrm{BC}$ & & & & & & \\
\hline $6 \mathrm{BC}$ & \multirow{10}{*}{ Phase 5A } & & & & & \\
\hline $7 \mathrm{BC}$ & & & & & & \\
\hline $8 \mathrm{BC}$ & & & & & & $\begin{array}{l}\text { Gradual drying, } \\
\text { run-off reduction }\end{array}$ \\
\hline $9 \mathrm{BC}$ & & & & & & \\
\hline $10 \mathrm{BC}$ & & & & & & \\
\hline $11 \mathrm{BC}$ & & & & & & \\
\hline $12 \mathrm{BC}$ & & & & & & \\
\hline $13 \mathrm{BC}$ & & & & & & \\
\hline $14 \mathrm{BC}$ & & & & & & \\
\hline $15 \mathrm{BC}$ & & & & & & \\
\hline $16 \mathrm{BC}$ & \multirow{5}{*}{ Phase 4} & & & \multirow{5}{*}{$\begin{array}{l}\text { Arrival from } \\
\text { outside region: } \\
\text { establishing } \\
\text { a place in the } \\
\text { landscape }\end{array}$} & & \multirow{5}{*}{$\begin{array}{l}\text { Warm, humid, } \\
\text { lakes and swamps } \\
\text { on floodplain }\end{array}$} \\
\hline $17 \mathrm{BC}$ & & & & & & \\
\hline $18 \mathrm{BC}$ & & & & & & \\
\hline $19 \mathrm{BC}$ & & & & & & \\
\hline $20 \mathrm{BC}$ & & & & & & \\
\hline
\end{tabular}

Figure 1. Synthesis of the major social and environmental trends in the upper Mun River valley over the past 4000 years. The boldness of the horizontal lines indicates the importance or significance of the change or difference between phases 
We now discuss the geoarchaeological and archaeological materials and data specific to our case study before returning to the wider implications of the case study in later sections of this paper.

\section{Geoarchaeological insights}

\section{Overview}

Thereare several strands of evidence that bring us to these conclusions; published in detail elsewhere (summarised by Boyd 2007), they are synthesised here. To open, it is important to understand the geological setting of the archaeological sites (Figure 2; Boyd and Habberfield-Short 2007); the published regional geological history, together with details of field observations, combine in a model of the palaeogeography of the region (Boyd 2007) (Figure 3). That palaeogeographic model identifies several key landscape periods: Palaeogeographic Phases 1 to 3 represent the establishment of the landscape into which people eventually moved; Palaeogeographic Phase 4 represents the early to mid-Holocene period of environmental stability and richness; whereas Palaeogeographic Phase 5 reflects a mid to late-Holocene period of critical environmental

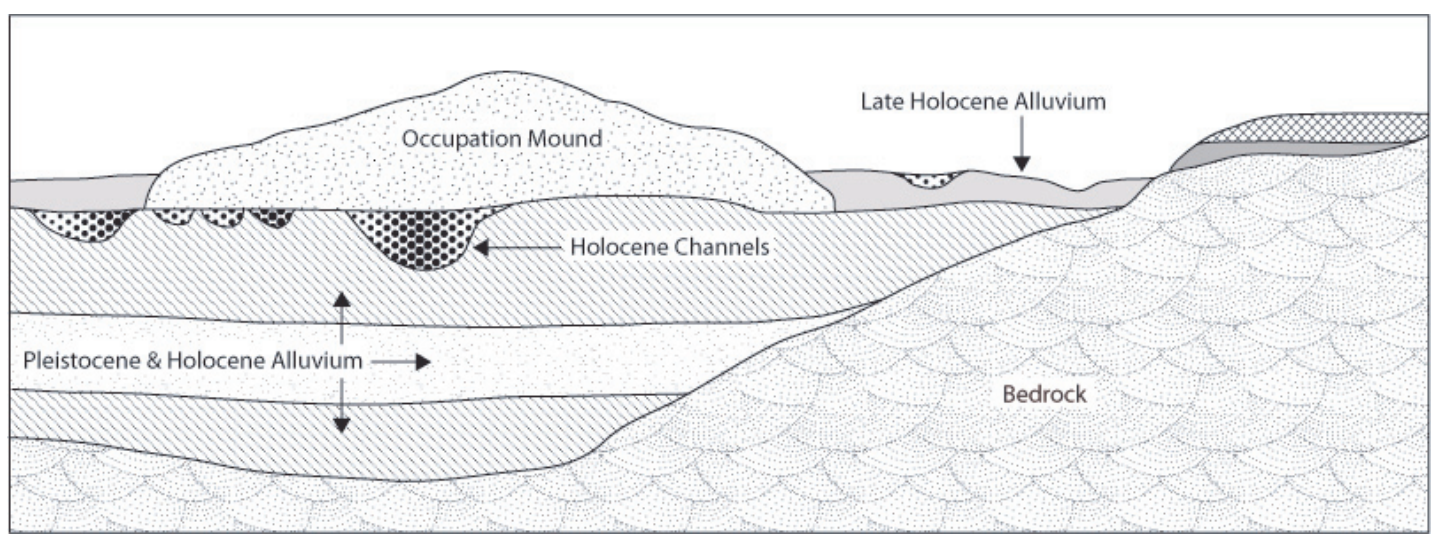

Figure 2. The geological context of the archaeological sites of the upper Mun River valley floodplain

\begin{tabular}{|c|c|c|}
\hline Palaeogeographic phase & Key geographic processes & Social implications \\
\hline $\begin{array}{l}\text { Phase 6: Late Holocene (AD } \\
\text { 500-present) }\end{array}$ & $\begin{array}{l}\text { Alluvial conditions include single } \\
\text { channels and sheet wash, onset of } \\
\text { modern climatic conditions }\end{array}$ & $\begin{array}{l}\text { Establishment of historic and } \\
\text { modern modified and degraded } \\
\text { landscape }\end{array}$ \\
\hline \multirow{3}{*}{ Phase 5: Mid to Late Holocene } & $\begin{array}{l}\text { Phase 5C (200 BC-AD 500) } \\
\text { Increasing dryness and seasonality }\end{array}$ & $\begin{array}{l}\text { Increasing landscape management } \\
\text { and engineering }\end{array}$ \\
\hline & $\begin{array}{l}\text { Phase 5B (BC 500-200) } \\
\text { Anastomosing channels, reduced } \\
\text { runoff, drier floodplain }\end{array}$ & $\begin{array}{l}\text { Mixed economy settlement, } \\
\text { tendency towards increased } \\
\text { landscape management }\end{array}$ \\
\hline & $\begin{array}{l}\text { Phase 5A (BC 1500-500) Channel } \\
\text { infilling }\end{array}$ & Settlement by rivers \\
\hline $\begin{array}{l}\text { Phase 4: Early to Mid Holocene } \\
(6000-1500 \text { BC) }\end{array}$ & $\begin{array}{l}\text { Floodplain deposition, braided } \\
\text { channels to single-string channels, } \\
\text { back swamps, lakes }\end{array}$ & $\begin{array}{l}\text { Rich aquatic environment and } \\
\text { important resource source for early } \\
\text { settlement }\end{array}$ \\
\hline $\begin{array}{l}\text { Phase 3: Late Pleistocene } \\
(12,000-6000 \mathrm{BC})\end{array}$ & Hiatus & \\
\hline $\begin{array}{l}\text { Phase 2: Mid to Late Pleistocene } \\
\text { (to 12,000 BC) }\end{array}$ & $\begin{array}{l}\text { Regolith stripping, coarse sandy river } \\
\text { channels }\end{array}$ & $\begin{array}{l}\text { Establishing the landscape for } \\
\text { human settlement }\end{array}$ \\
\hline Phase 1: Mesozoic-Tertiary & Bedrock formation and weathering & \\
\hline
\end{tabular}

Figure 3. A palaeogeographic model for the upper Mun River valley, linking the geological record of the floodplain with its key geographic processes and social implications arising from these 
change; and the final Palaeogeographic Phase (6) represents a modified environmental stability, as the changes during the previous phase resulted in a new landscape equilibrium.

\section{Vegetation history}

There is pollen evidence for Palaeogeographic Phase 5 (Boyd and McGrath 2001a, b), indicating that by the early Iron Age (c. 200 BC-AD 1), the natural forest of the floodplain had been disturbed and was now partially open; given the archaeological evidence for previous settlement and rice cultivation, this is unsurprising. During the Iron Age, there are cycles of further forest disturbance and the establishment of rice cultivation, woodland management and arboriculture, the latter coming in later in the sequence: during the mid-Iron Age (c. $\mathrm{AD} 300$ ), forest clearance, rice cultivation and some woodland management is followed by a period of forest and woodland regeneration, and then the resumption of rice cultivation accompanied by arboriculture. The period of forest and woodland regeneration is notable, in that, despite the environmental impact of human activities, local vegetation had the capacity to recover. Finally, however, during the late Iron Age, a decline of agriculture and arboriculture was accompanied not by forest and woodland regeneration but by the establishment of grassland and scrubby vegetation. Linked with other archaeological evidence, for example wild animals and other fauna, we can model the trend of vegetation change during the late Holocene (Figure 1). This model, in particular, charts the gradual and sequential shift from stable Holocene conditions of a floodplain forest, through increasing and varying forms of vegetation disturbance and change, to the eventual conversion to late-Holocene conditions of dry woodland.

Clearly, such a vegetation history could be read largely, and conventionally, in terms of the human impacts on vegetation. However, it perhaps more accurately reflects the continuous and variable interaction between people and the vegetation of their environment. While it is largely the effects of people that best explain the conversion of floodplain pioneer forest to managed forest and, eventually, to agricultural landscapes during the Iron Age, it is also clear that the vegetation had a capacity to regenerate where agricultural pressure declined. This provides evidence that natural ecological processes still prevailed and provided opportunities for both people and their environment to continually evolve in their functioning requirements. The rise of arboriculture later in the sequence also indicates the potential for environmental processes to adapt to changing conditions, and thus while forest was on the decline, it was possible, as in many parts of the world, for this structural element to be replaced by an equivalent vegetation. Moreover, this model of vegetation change suggests there were several long periods of change, reflected in both the vegetation and social histories. In particular, three phases of change are in evidence: a gradual early prehistoric forest change during the Neolithic and Bronze Ages into the early Iron Age (c. 2500 BC to 200 BC); a more rapid period of Iron Age landscape management producing phased and sequential change from c. $200 \mathrm{BC}$ to $\mathrm{AD} 500$; and a rapid immediately post-Iron Age transition at c. AD 500 to AD 600, where the Iron Age agricultural landscapes were replaced by the dry woodlands and grasslands of the late Holocene.

\section{Palaeohydrology}

Crucial to these vegetation changes are the shifts in hydrology identified for this floodplain (Figure 1). Initial recognition of the sites was founded on the identification of encircling earthworks interpreted as defensive and water-management features. Subsequent geoarchaeological study (Boyd et al. 1999a, b; McGrath and Boyd 2001; McGrath et al. 2008) developed a model of the earliest settlement being along prehistoric rivers. Importantly, these rivers represented a period where the floodplain was better watered than at present, and where the rivers that did flow across the floodplain were more abundant, of a different 
form, and differently located to those at present. Importantly, the early rivers provided suitable locations and resources for the human occupation of the floodplain, with settlements becoming established along the banks of the many rivers. Archaeological evidence is clear on this matter, with former river channels being found at the bases of excavations. In due course, these river channels became increasingly managed, with evidence initially for relatively minor modifications, the cutting of channels across oxbow cut-offs to produce bodies of water fully encircling the settlements, and the periodic cleaning out of the channel bottom sediments. This might be described as adaptive engineering, and may represent the need or perceived need to ensure a reliable supply of water to the sites, changing demands on water supply, or a reaction to changes in water supply reliability.

In time, however, the situation had changed to a point where constructive engineering was called upon. By this stage, either demand for a reliable supply of water was increasing beyond the system's capacity or the supply of water was declining. It is also clear that by then individual settlements had grown to such an extent that they were expanding over the former encircling water bodies and infilling them. Whatever the immediate cause, people began to construct new encircling water bodies, probably in imitation of the natural and adapted water bodies that appear to have supplied water for so long. This period of constructive engineering was quite short lived, and did not produce the desired effects; sedimentary evidence demonstrates that during the late Iron Age such channels infilled quickly with sediments. Whereas the earlier channels were filled up with clay best explained as the natural catchment sediment, and thus representing catchment run-off, the later channels were infilled by suspended floodplain sediment, representing in-situ rainfall flooding rather than catchment through-flow. While this engineering response did not manage to reproduce the effects of the previous regime of river flow, the evidence also suggests changing hydrological and possibly climatic conditions, a probable reduction in rainfall, or at least in the reliability of rainfall. The evidence of rainfall flooding may signal the onset of increasing seasonality in climatic conditions (cf. Maxwell 2001; Maxwell and Liu 2002).

\section{Environmental explanations for change}

This geoarchaeological evidence would, it has to be acknowledged, provide satisfactory stories of the past, details of the stage on which society acted, accounts of the resources it used, and a history of the changes it wrought on nature. In this way, the various environmental trajectories and especially their conclusion towards the end of the Iron Age can in tandem be explained in a variety of conventional biophysical, climate-change or human-impact ways (Boyd 2008). Typical of such explanation would be discussions of soil and vegetation change, past disruption of regeneration ecology, changes in riverbed loads, critical catchment changes, or specific local biophysical processes such as salt-dome upwelling. Finally, there is always climate change. A key idea in Quaternary geology is that processes such as climate warming or changes in rainfall abundance or patterning provide convincing evidence for changing environmental conditions. While the conclusions of such discussions do provide useful contextual interpretation, we are more interested in the ways in which such stories interact with the people who are the direct subject of the archaeological investigations. Before we turn to that relationship, we describe the archaeological evidence for our case study.

\section{Archaeological insights}

\section{Overview}

We can now turn to the archaeological material culture and stratigraphic evidence from, in particular, Ban Non Wat and the later Iron Age deposits at the neighbouring site of Noen U-Loke. Reference will be made to other sites as appropriate. It is important to note that 
analysis of the material from Ban Non Wat is still underway, and that many of the following observations necessarily reflect our (especially Chang's) personal impressions. There is much debate over the analysis and interpretations still to be had.

With these caveats in mind, we return to Figure 1, in which both apparent internal social change and outside (regional) social influences are identified as important in understanding the integrated pattern of social and environmental change over time. Turning first to the internal developments, six characteristics have been identified (Figures 4 and 5): burial practice, burial patterns (cemetery layout), types and materials of grave goods, variety and quantity of grave goods, exchange and contact, and, finally, evidence of warfare.

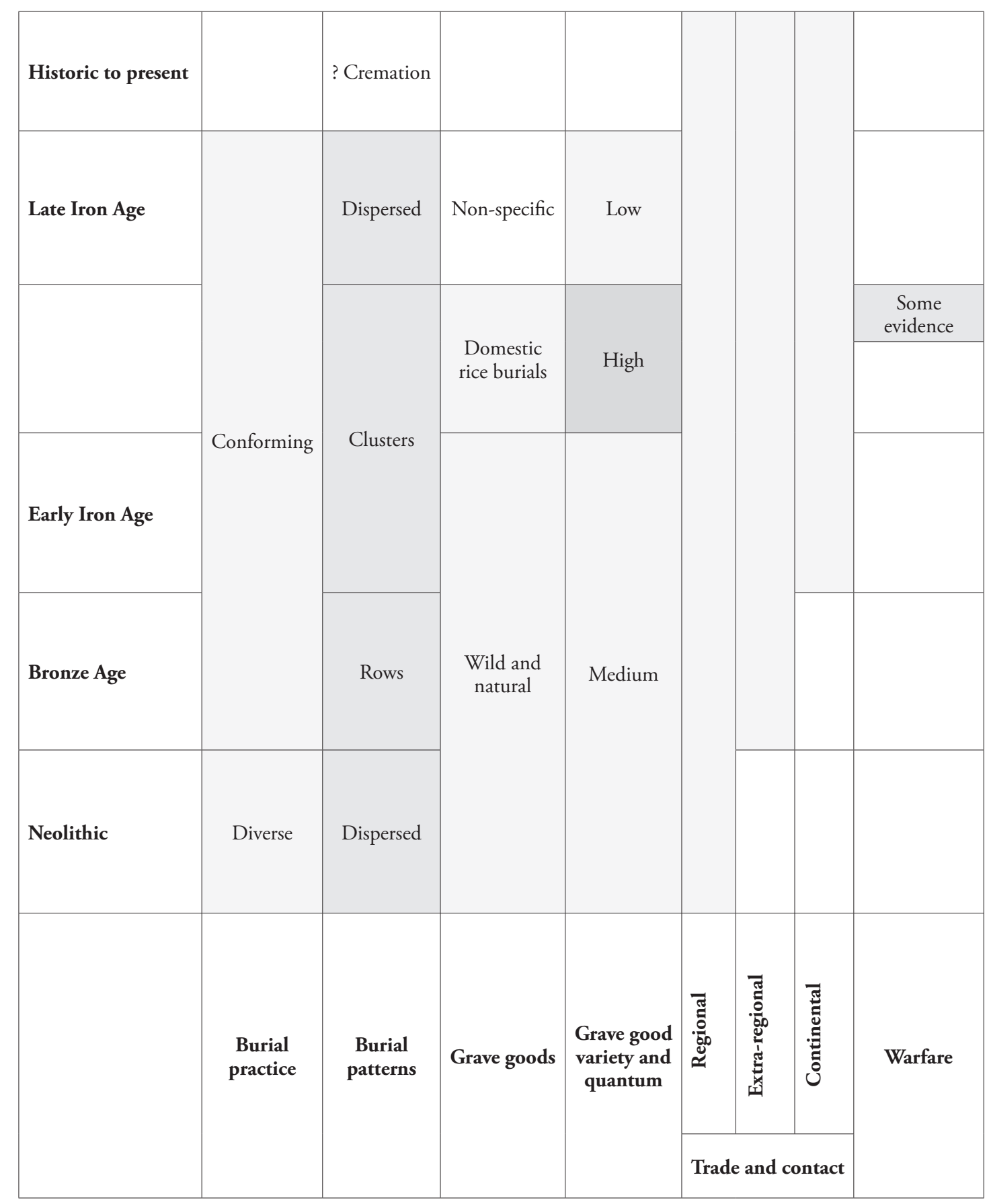

Figure 4. Schematic illustrating the trends in social activity and change throughout the late-Holocene settlement of the Mun Valley; the columns represent broad categories of social activity as witnessed by the archaeological record, which are characterised in broad terms. The schematic indicates that for each broad category of social activity there has been significant change; the heavy lines represent periods of significant change 


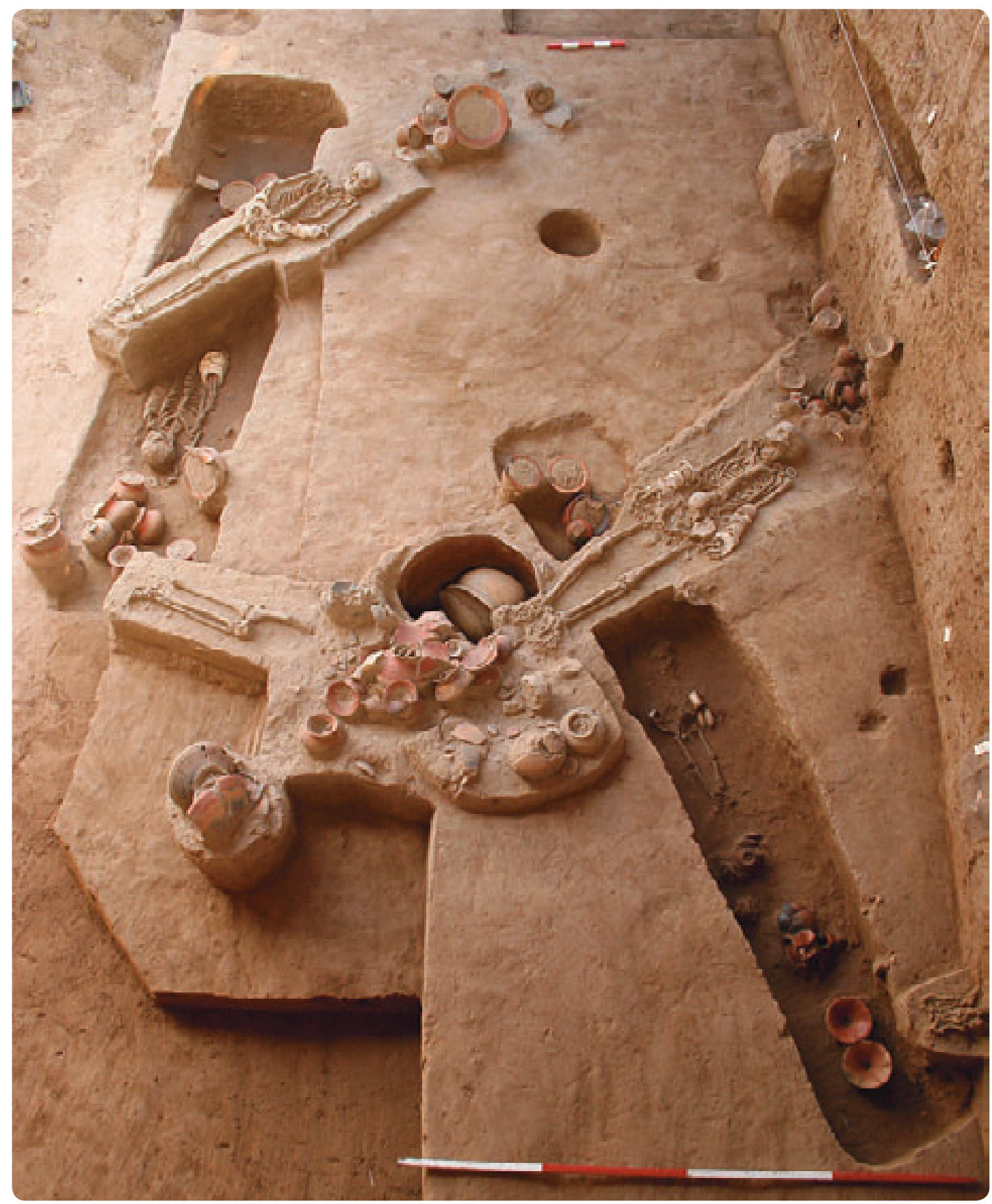

Figure 5. Photograph of exposed Neolithic and Bronze Age graves at Ban Non Wat, February 2005. Note the different alignments of the overlying rows of Bronze Age burials. The partially disturbed (incomplete) burial running across the lower central part of the picture is Neolithic, while the deeper graves aligned roughly north-south (north is at the top of the picture) are actually dated to the later Bronze Age. Photograph N.J. Chang

\section{Burial practices and patterns}

Burial practice and burial pattern at Ban Non Wat reveal a distinction between Neolithic diverse practices and widely dispersed graves, and the more conforming Bronze and early Iron Age graves. During the Neolithic, some individuals were buried crouched in large pots, some in roughly east-west and others in north-south oriented extended graves. Some graves include freshwater gastropods and pig bones, others not. The most obvious feature is the lack of rows or clusters in the distribution of Neolithic graves. One reason for this variety may be that the Neolithic at Ban Non Wat extends over a possible 800 years from roughly 2100 to 1300 $\mathrm{BC}$ (Higham pers comm., unpublished radiocarbon dates). If this is the case, then it further 
emphasises the sparse distribution of graves from this period. Further to this, we should note the relative lack of sediment deposition during this period. In many cases, Bronze Age graves are cut down through Neolithic deposits, leaving the skeletal remains of early Bronze Age individuals deeper below the surface than the earlier Neolithic remains. By the Bronze Age, however, it is clear that graves are being placed in clear and conscious relationship to one another. There is something of a transition evident. The earliest Bronze Age graves are very large and replete with grave goods. They are also relatively widely dispersed across the excavated area. Those that follow are placed in neat rows. Over time, the orientations of the rows vary and the individual graves appear to be placed increasingly close together. As iron working becomes apparent, the graves become clustered, so much so that excavating individuals, and identifying to which grave various grave goods belong, becomes very difficult. Turning to Noen U-Loke for the later Iron Age, we see that clusters remain the major organising principle well into the first millennium AD (Higham 2002; Higham et al. 2007). However, sometime after $\mathrm{AD} 300$, burials become more dispersed. Talbot (2002) has interpreted this as reflecting a breakdown of local social organisational systems.

Grave goods are an important characteristic of the mortuary evidence, as well as being useful indicators of the extent of exchange relationships. There appears to be a general trend at Ban Non Wat and Noen U-Loke towards an increase in quantity and, more clearly, in variety of grave goods over time. A second trend is towards grave goods of increasingly distant origin or, put another way, the participation of the upper Mun River valley people in increasingly extensive exchange networks. The third and most interesting trend seems to be from wild materials and objects to materials and objects of more domestic inspiration. All three of these apparent trends require explanation.

The Origins project began with excavations at the Bronze Age site of Ban Lum Khao (Higham and Thosarat 2005). The remains from this site have been described as relatively poor, and the comparison with the following excavations at Noen U-Loke was clear. Particularly in terms of personal ornaments, the number and variety of grave goods were orders of magnitude greater at the Iron Age site (Chang 2002). However, the discovery of large and well-endowed graves in the early Bronze Age at Ban Non Wat questions this interpretation. The impression that the Bronze Age was significantly poorer or less hierarchical than the Iron Age in the Mun River area may simply be the result of sampling error or bias. At Ban Lum Khao, excavations were undertaken near what was probably the edge of the prehistoric occupation, while at Noen U-Loke and Ban Non Wat, the excavations are closer to the centre of the site.

At Ban Non Wat, there still remains, however, a distinction between the Neolithic graves, which contain relatively fewer and less diverse grave goods, and the more subjectively impressive graves of later periods. In this context, it should also be noted that pottery was an important grave good in all periods. The styles and decorative elements vary, but it is clear that some thought and time was given to providing appropriate ceramic inclusions in mortuary rituals from the time that Ban Non Wat was first occupied. It may be appropriate to consider pottery as a common, background element in mortuary ritual; a base from which variation and diversity develops.

\section{Regional trade and contact}

This impression of greater variety over time may derive relatively directly from the wider exchange relationships that were developing. During the Neolithic, there is actually little evidence of extended exchange relationships at Ban Non Wat. The most intriguing exception is the presence of modified cowrie shells with two of the Neolithic burials. The most obvious interpretation is that there was some relationship with parts of China, where such shells were being used as currency about the same time (c. 4000 years ago). During the Bronze Age, large quantities of marine-shell jewellery seem to indicate well-developed networks between the 
Khorat Plateau and the ocean. The question remains whether these were overland and via the Chao Phraya river system westwards, or whether they followed the Mun and Mekong route to the east coast. Tridacna sp. (giant clam) dominates in the earliest Bronze Age burials, while armbands and bangles of Trochus sp. dominate in the later Bronze Age. A continued connection of some sort with China is implied by the presence of T-sectioned bangles (usually made from marble) across Southeast Asia during the Bronze Age, including at Ban Non Wat (Chang 1996, 2002).

During the Iron Age, it is well known that agate, carnelian and glass beads indicate some sort of contact with distant Indian sources and ideas (Glover 1998; Higham 1989, 2002; Bellina 2003; Theunissen 2003). These artefacts are regular finds across northeast Thailand. Other jewellery items at Noen U-Loke, such as gold beads, suggest participation in networks that reach to the mouth of the Mekong, north up the Vietnamese coast, and south into Island Southeast Asia. By the end of the sequence at Noen U-Loke (after AD 300), distinctive finger rings found with one individual suggest direct relationships with the Dvaravati culture sites of the Central Plains of Thailand (Chang 2002). Of course, it is in the first few centuries AD that places such as Oc Eo and the developing state of Funan are thought to begin participating in a 'World Trading System' (Glover 1998). The people of the upper Mun River valley were in some way connected to this system, if at one or two removes, during the latest burial phases at Noen U-Loke (Chang 2002).

\section{Social interaction with natural resources}

While quantity and variety of grave goods and the distances from which they are derived are all increasing, there is a parallel movement from 'wild' to 'domestic' grave goods. It may be that the causes of this trend are more closely tied to local environmental and social changes. This change was first identified at Noen U-Loke, where the earliest Iron Age graves include pendants made of pig's tusks and tiger canines (Chang 2002; Talbot 2002) (see also Chang and Voelker 2003 for an argument as to the symbolic significance of personal ornaments as grave goods). These parallel grave goods found at Ban $\mathrm{Na}$ Di that include an alligator skin shroud and a dog's tooth necklace (Higham and Kijngam 1982; Higham 2002). Extending back into the Bronze Age at Ban Non Wat, we note again the predominance of Tridacna sp. and Trochus sp. armbands and bangles. In contrast, as the Iron Age progresses, we see at Noen U-Loke a clear change such that rice becomes a significant grave good itself. This is the most obvious domestic element. Along with the domestic product, tools such as iron spades, knives and possible sickles become common grave goods (Higham 2002; Higham et al. 2007). The important point here is that while it is considered that the first inhabitants at Ban Non Wat (and their contemporaries elsewhere in northeast Thailand) were rice farmers, it is not until the later Iron Age that they chose to stress this part of their life in their mortuary rituals. We suggest, as has Talbot (2002), that this may reflect a social response to a deterioration of the environment. Our argument is as follows (and is reflected in the model we propose in the final section of this paper).

- The initial Neolithic colonists at Ban Non Wat (and presumably elsewhere on the Khorat Plateau) arrived with a mature rice-growing technology as part of their subsistence toolkit.

- Perhaps because during the process of adaptation to the local environment rice agriculture became only a part of their subsistence strategy, or alternatively, perhaps because the local conditions allowed rice to grow so easily, the paraphernalia and products of this activity were not stressed in their ritual practices, certainly not in mortuary ritual. Psychologically, it was not uppermost in their minds. Ritual activities centred on exchange relationships and interactions with the natural world. 
- However, during the Iron Age, environmental changes made the growing of rice a more difficult process. This concentrated their minds on what it was they actually did; how they subsisted. Parallel to an increased effort in moat and bank construction to control the increasingly problematic water resource, there was an intensification in ritual activity - for the same reason. Ritual activity was the only opportunity for affecting rainfall and other aspects of the agricultural round, and as these variables began to fail, an obvious response was to increase the ritual response.

In a sense, this parallels Higham and Lu's (1998) arguments about the initial development of rice agriculture in the middle Yangtze River. Environmental change instigates a behavioural response that involves a level of choice. The choice that people make is to change or intensify current practices in order that the overall lifestyle can be maintained. Clearly, the people of Ban Non Wat and Noen U-Loke could have opted to leave the area as agriculture became more difficult or they could have further adapted their subsistence system to the changed natural resources. What they chose to do was to attempt to maintain their current (ricecentred) lifestyle by an intensification of both physical and ritual practices. They changed in order to remain the same.

\section{Warfare and conflict}

We turn now to evidence of warfare and conflict in the region, and the relationships with the developing state societies in the lower Mekong River and its delta. At Ban Non Wat and Noen U-Loke the evidence is limited. A single individual at Noen U-Loke in the middle Iron Age was buried face down and with an iron arrowhead embedded in the spine (Higham 2002; Higham et al. 2007). While this is clearly evidence of a violent death, it does not necessarily imply organised or endemic warfare. It is interesting that the early Iron Age burials at Ban Non Wat include large bimetallic spearheads (iron blade and a bronze socket) that are thus far absent from the later Iron Age at Noen U-Loke. In the absence of other martial evidence, it is not unreasonable to hypothesise that these were used for hunting rather than for warfare. A simple contrast can be made with the site of Phum Snay in northwest Cambodia dating to the first centuries $\mathrm{AD}$ (that is, broadly contemporary with the middle to later Iron Age in the Mun River system), where iron swords are common grave goods and there are caches of projectile points (O'Reilly and Sytha 2001). Clearly, quite different levels of conflict were apparent there.

It must be remembered that it was also during the first centuries $\mathrm{AD}$ that the historically known state of Funan was developing in the Mekong Delta. Phum Snay was considerably closer and potentially in more direct contact with Funan, while any effects from, or response to, such a new form of society in the region for the upper Mun River would have been mitigated by the physical barriers of the Daeng Raek escarpment and the major rapids in the Mekong below its confluence with the Mun. Elsewhere, Chang (2001) has argued that if we accept that the major routes of exchange and contacts were along the rivers, then societies at nodal points, such as the confluence of the Mun and the Mekong, would also have operated as filters through which the traffic of ideas and influence would have been constrained and objects mediated.

\section{Regional influences}

Our argument here is that while materials and objects made their way into the Mun River system, they came via various routes and we should not assume a direct connection between, or even any real knowledge of, representatives of Funan (and following states) and the people of Iron Age Ban Non Wat and Noen U-Loke. The obvious question that follows is: what about the development of an Angkorian centre at Phimai, and Dvaravati-inspired centres such as Muang Sema in the upper Mun catchment? We return to this question again below, but essentially our answer is that as environmental changes made agriculture more difficult, an eventual direct 
impact on the lower Khorat Plateau by the early states would have provided new options and possible responses to these environmental changes. There may have been a very rapid uptake of new religious ideas and organisational strategies if these were seen as having more potential for mitigating environmental change. In a sense, this is an extension of the rice-in-mortuary-ritual argument above. A drive to intensify ritual responses to environmental change could have seen the uptake of new, potentially more powerful, ritual systems such as Buddhism and Hinduism. In the archaeological record, this would be reflected in a sudden truncation of indigenous cultures, adaptations and trajectories. This may be what archaeologists are seeing when they note that there appears to be an abandonment of the moated sites marking the end of the Iron Age at about $500 \mathrm{AD}$ (Welch and McNeill 1991). We have already noted above that this abandonment may be more apparent than real - at Ban Non Wat, for example, there is considerable evidence for continued occupation throughout the ensuing proto-historic and historic periods. Rather than abandonment, we may be seeing a significant and very fast cultural change.

\section{Geoarchaeology and archaeology: Landscapes and people}

\section{Conceptual evolution of the prehistory of the study area}

Our archaeological and geoarchaeological discussion, in broadly seeking to establish the geography of the landscape before, during and after human occupation (Boyd et al. 1996a, b), has specifically set out to determine reasons for differences between past social and environmental richness and present environmental fragility. This comparative heuristic makes it possible to further understand past intimate human-environment relationships. In particular, we have identified very different past hydrological and climatic conditions as being important influences on social possibilities. This is highlighted in a spectacular, and in some ways conventionally familiar, way by what appears to have been the collapse of, or at least a significant shift in, the environment at the end of the Iron Age. This event may, however, be more apparent than real (as with the idea of site abandonment at the end of the Iron Age), and can, interestingly, be ascribed to a set of ideas in place before our detailed research. For example, at the onset of the research, received thinking assumed that these 'moated' sites represented solely the Iron Age, and marked a distinctive and seemingly evolutionary shift from prior subsistence farming to a more strongly structured and hierarchical society. Because the encircling earthworks had been labelled as 'moats', they took on the identity of defensive structures, thus suggesting conflict (WilliamsHunt 1950; Boyd 2007).

Further presumptions confounded the situation: the initial observation that these moated sites by and large lay distant from present rivers led researchers to assume a complex Iron Age socially and technologically organised canalised landscape, constructed in contrast to any prior landscape. In these conceptualisations, the Iron Age was seen as notably different from previous periods, reflecting contemporary global views of the Iron Age, and presenting a stage in social evolution that both imposes higher-order organisation on the use of resources, and acts as an essential stepping stone towards the emergence of complex societies.

\section{Refocussing the questions}

Our views of the prehistory have, however, shifted considerably. We now know that the landscape was occupied since the Neolithic (c. 2500 BC onwards), an occupation that is better characterised largely as a long, continuous, stable and healthy prehistoric occupation. Settlement was by an ancient river system, and represented a continued and dynamic use of rich environment resources, paralleled by dynamic social structures and dynamic technological development. In particular, key signatures of this long-term stability appear to be sophisticated, responsive and evolving water management and changing relationships with other natural 
resources (plants and animals), reflecting complex interactions with changing environmental conditions. It has become clear that environmental conditions have an important influence in defining patterns, and especially continuity, of settlement and occupation. In particular, the evidence now to hand implies close and complex relationships between social and environmental processes and change.

In this context, it is interesting to contrast the initial intentions of the geoarchaeological research with the outcomes of more than 10 years of such work. Geoarchaeological investigations set out initially to answer questions regarding: the lack of a canalised landscape (where were the canals?); the characteristics of the moats and their use, especially regarding defence (where are the palisades?); the environmental conditions of a unique Iron Age that distinguished it from previous periods (what was special about the Iron Age climate and the seemingly advanced social response to climate?); and the cause of the dramatic end of the Iron Age (what were the climatic and/or social events that caused site and moat abandonment?). As the research progressed, it became increasingly clear that human relationships with the landscape were more consistent than not over time, and that the Iron Age represents a natural, progressive landscape-adaptive response to slowly shifting environmental and social conditions.

\section{Environmental determinism or cultural opportunity?}

Therefore, while a regionally significant climatic shift may have provided a critical change at the end of the Iron Age around AD 600, it now seems much more likely that the Iron Age society maintained a much longer social tradition, adapting gradually to long-term environmental (climatic, ecological and hydrological) change, using sophisticated water engineering linked to agricultural change. That is, long periods of environmental constraints were expressed through gradual shifts in social behaviour. Eventually, the point arrived where the established social and engineering solutions that supported social sustainability during periods of environmental uncertainty, declining water supply and supply reliability were no longer able to moderate the effects of environmental change. By the end of the Iron Age, the Dvaravati civilisation of central Thailand was expanding into the region, closely followed by Khmer influences, bringing different and novel social solutions to environmental challenges, and thus providing the opportunities for the creation of new landscapes. But we are running ahead of ourselves; first to the details of our geoarchaeological and archaeological evidence.

\section{Discussion}

\section{Overview}

What do these seemingly diverse records of environmental and social phenomena mean in terms of the prehistoric human settlement of the upper part of the Mun River valley? Before we answer this, it is important to return to the central conceptual foundation of our approach. Our primary question has been: Can an integrated socio-environmental approach - in other words, a landscape approach - provide good explanation of prehistoric conditions? In part, asking such a question is a response to previous approaches to archaeology in the region, in particular, a tendency towards privileging society over environment that does not sit comfortably with widespread observational evidence of the intimate relationship between people and environment (e.g. Boyd 1988; Knapp and Ashmore 1999).

There are many archaeological models for social change - social, cultural, technological, environmental, migration, etc - but they tend to favour individual processes, and are often socio-politically based. The conventional assumption of an Iron Age in Thailand that is distinctively different from the preceding Bronze Age and is structured more like Iron Age societies elsewhere in the world, with a focus on chiefly structures, warfare and defence, is one 
such example (for a different view incorporating a heterarchical heuristic in Southeast Asia see, for example, O'Reilly 2003 and White 1995). In many ways, it is relatively easy to consider a single driving force in social or cultural change, especially where evidence - archaeological in this case - is by its very nature limited.

\section{Landscape as culture}

However, from a geographical point of view, landscape is fundamentally important. Landscape both provides a foundation for, and represents the synthesis of, all social and biophysical processes, and, by definition, is integrated and complex. It may have many properties - physical, biological, social, cultural - and in character it can be temporary, changing or interlinked. Importantly, geographers understand landscapes as cultural constructions, and use them as a valuable heuristic to examine the complexity of the human condition, the ways in which societies organise their social, technological, economic, cultural, spiritual and ritual behaviours, and thus define themselves. Cultural landscape concepts, for example, emphasise the connectedness rather than the singularity of individual sites (e.g. Head et al. 1994; Ross 1996) and the importance of landscape and environment in understanding past human behaviour (e.g. Butzer 1982; Lasca and Donahue 1990). An individual place, event or person therefore ceases to be isolated, but is relocated within sets of parallel, particular and cognitive landscapes constructed under the influence of many social and cultural parameters (Tuan 1974, 1977; Gould and White 1986). The individual therefore becomes one node within overlapping networks of physical, social, cultural and political linkages, pathways, edges, landmarks and surfaces (Boyd et al. 1996a, 2005). In this way, landscapes remind us of the essential links between people and places, and can only be fully understood in terms of both the physical and social processes enacted on them, and the ideas imposed on them and derived from them. Implicit in such a model are concepts of, for example, mutual influence, process relationships, feedback, change and cultural construction. In short, landscapes not only shape human experience, but are also shaped by that very human experience (Bender 1993).

\section{The role of environment in archaeology}

Given this, it remains to comment on the role of environment in studies of ancient social change. It is worth repeating that environment is used in archaeological studies in many ways. Typically, it often provides a passive background (a stage for people) or a deterministic control (people as automatons) for social behaviour. Alternatively, it can be conceptualised as a resource, a source of natural resources (utility), or something to be modified by people (people as controllers). Clearly, we take a different view. While all of these characterisations of environment relative to people can be correct in a non-exclusive way (environment can provide a background for social action, for example, and may in some circumstances provide a deterministic cause-and-effect driver), for a more complete understanding of social change, environment must be viewed as an active element, influence or process in social change. Applying this approach brings archaeological investigations closer to geographic understandings of people as part of the environment and environment as part of society - in other words, to the integrating concept of landscape. Even using landscape, however, fragmentation is possible. Bradley (1997), for example, draws the distinction between landscape archaeology's focus on settlement and subsistence, and social archaeology's interest in ritual and ceremony. Any observation of the human and social diversity of behaviour evident across the world supports claims that the integration of people and environment is a tangible and real entity. Articulated in the concept of landscape, the 'material manifestation of the relationship between humans and the environment' (Crumley 1994), such observation denies any claims that people ignore their environment, are obligated to respond in pre-ordained ways to environmental constraints, operate separate from their environment, or simply quarry it for resources without redefining 
themselves. In contrast to what Knapp and Ashmore describe as the minimalist situation 'landscape as the backdrop against which archaeological remains are plotted' - we favour their emphasis on landscape as socio-symbolic: 'landscape is an entity that exists by virtue of its being perceived, experienced, and contextualized by people' (Knapp and Ashmore 1999).

Adopting such an approach, it may be questioned exactly how geoarchaeology, given its strong biophysical or earth-science tradition, can contribute to archaeological interpretations and model building. Here we demonstrate a two-stepped approach. Step one commences with a conventional geoarchaeological question: What was the local geography like before during and after ancient occupation? To answer such a question, we follow standard geoarchaeological procedures (Rapp and Gifford 1986; Waters 1996; Rapp and Hill 1998) in our application of the physical sciences, applying techniques borrowed from geology, geochronology, physical geography and chemistry to help understand the biophysical nature of the landscape and its evolution during the prehistoric period of interest.

Such study is valid, and indeed has provided a detailed set of descriptions of the biophysical conditions in the study area. Importantly, it tends, however, to discount complex humanenvironment interaction. The second step, therefore, is important for us. Here is where we move on to integrate such biophysical information with the body of emerging archaeological evidence. In doing so, our focus shifts to mutual social and environmental processes, feedback and interactivity, and cultural construction complementing physical and social processes.

\section{Integrating social and environmental dynamics}

Integration of social and environmental trajectories (Figures 1, 3 and 4) draws parallels with context and behaviour. Initially, there are clear social implications of the geological and biophysical history, in which environmental opportunities and limitations are important. More importantly, examining the various changes identified in both the geoarchaeological and archaeological studies reinforces an alignment between social and environmental processes. What this comparison does is reinforce a history of evolving relationships between water, vegetation and people. That history traces a model of late-Holocene landscape evolution, influenced by intimate relationships between internal and external social and environmental processes. This evolution spans the development of a landscape of mid-Holocene optimal conditions being settled and adapted, through to a critical change resulting in a new equilibrium landscape. It is in this new landscape, emerging about AD 500, that the Khmer established their important presence in the early historic period.

The whole history can be modelled as a sequence of shifts representing a trajectory from the mid-Holocene period of the Neolithic occupation of the floodplain to the post-Iron Age. As for the histories of vegetation and hydrological change described above, the archaeological trajectory can be modelled in terms of critical changes. Furthermore, there is a relatively long early period (1500 to $300 \mathrm{BC}$ ) of gradual river modification, extending throughout the times of Neolithic and Bronze Age settlement, and into the early Iron Age, during which adaptive engineering gradually modified the natural channels around the settlement sites. During the late Iron Age, around AD 300, a second phase of change is evident, with the phased introduction of constructed channels. Importantly, these biophysical and social shifts need not be contemporaneous, and indeed their partial non-synchronicity is testament to the complex interactivity and resilience of both society and the landscape: both can respond and adapt to changing circumstances, and both can operate within broad limits during such change. The end of the Iron Age, a notably rapid period of change around AD 500 to 600, saw significant social and environment changes, the abandonment of sites and constructed channels, and the establishment of a new vegetational regime and the present regime of river flow. Many of these changes could be explained purely in terms of functional process: changing hydrological regimes, for example, coupled with social desire to maintain a comfortable lifestyle based on 
an adequate and reliable supply of water, encourages sequential technological shifts (adaptive engineering, followed by constructive engineering), which in turn become accommodated with the environment.

However, we can take the relationship between society and environment further than mere functional process. By considering both archaeological and geoarchaeological evidence of natural and agricultural resource use, patterns of change and exchange, forms of landscape patterning and adaptation, technological responses to common problems, etc, we can construct a model in which human and environmental behaviour becomes integrated and expressed through social identity. Social identity links behaviour, process and socio-environmental context, and is based on conceptions and construction of landscape, environment and geography (Boyd et al. 1996a, 2005). In our case study, the model comprises five interlocking process conditions and four characterisations of socio-environmental identity. This evolving social sense of place and self-identity broadly equates with the archaeological chronostratigraphy, and represents the intersection between environmental context, opportunities and constraints, and social behaviour and construction of beliefs, values and culture. Essentially, they provide a unifying statement in which people and their environment are treated equally, in which the processes and characterisations apply equally to both.

\section{Process condition 1: Colonisation (Neolithic)}

This phase refers to human entry into a (socially) empty (environmentally) optimal environment. Both society and the environment are adapting to the new conditions, people bringing external adaptations to their needs - farming, technology and social structures - which are suited to, and are absorbed into, the new environmental conditions. The environment, on the other hand, provides a suitable context to allow satisfactory settlement and social adaptation to natural conditions, and neither society nor environment appears to impose significant constraints on the other. Self-identity under these conditions revolved around arrival from outside the region with a prior social identity - the maintenance of classic Southeast Asian Neolithic pottery styles evidences a fully developed social identity, complex social structures and expression of values, and well-established farming techniques (e.g. Higham 2002; Bellwood 2004). The arrivals entered an environment well suited to their lifestyle and, importantly, their self-identity, adapting to it and modifying it to create local socio-environmental balance. Mid-Holocene environmental conditions were optimal and well suited to such settlement, and allowed the new settlers to slowly assume a localised identity associated with the specific conditions of the floodplain - best expressed in the next stage below.

\section{Process condition 2: Stability (Bronze Age and early Iron Age)}

This condition resides within the mid-Holocene, allowing long-term mixed social adaptation to optimal environmental conditions. Such a situation allows for gradual change, both of social and natural conditions, without major or significant disruptions. The social and environmental focus is internal, with social change reflecting localised trends and opportunities rather then external ideological shifts, and with environment not needing to respond to any external (e.g. climate) forcing. This condition represents a balanced socio-environmental equilibrium. Selfidentity shifts in emphasis, with the establishment of a more localised self-identity within society and geographical place grounded in the regional landscape, evidenced by indications of diversification of communities. Local communities' characteristics reflect the opportunities, resources and restrictions of the local environments, along with the choices made by each community (cf. Mudar and Pigott 2003). 


\section{Process condition 3: Forced Adaptation (middle Iron Age)}

This condition is characterised by an increasingly strong social use of the landscape, with environmental conditions conducive to adaptive landscape technologies. Change is driven increasingly by both external environmental processes and external social influences, and there is clear evidence for positive socio-environmental feedback on landscape change. Selfidentity again shifts in emphasis, towards the establishment of a regional self-identity, based on claims on landscape and place within regional networks. Society became, simultaneously, increasingly outward looking, both locally and regionally (for example, the incorporation of glass and other materials representing broader exchange relationships), and more centrally or locally focused. Evidence of increasing engineering responses to environmental change and increasing partitioning of the landscape point to a stronger sense of social claim on the landscape. Chang (2002) has argued, for example, that the very presence of moats around sites must have affected how the inhabitants saw themselves and their relationships with both neighbouring communities and the wider landscape.

\section{Process conditions 4 and 5: Tipping Point (Crisis) and Resolution-New Equilibrium (late Iron Age)}

The Tipping Point condition reflects a period of increasing social and environmental disequilibrium. External social forces provide increasing opportunity and need for social change, while environmental degradation, part internally and part externally driven, induces critical change. Eventually, both society and environment abandon adaptations (both vegetation resilience and engineering effectiveness, for example, decline), and there is further major environmental and social change.

The Resolution-New Equilibrium condition, on the other hand, represents a significant response to prior process conditions and an enforced major change of social behaviour within a non-optimal landscape. New ideas regarding alternative forms of social organisation from outside (Khmer, Dvaravati) become important. Associated with and emerging from these process conditions is an identity subsumed within an emerging centralised state landscape. This represents a significant shift from the trajectory of developing self-identity, and reflects the convergence of need and opportunity for change. The pattern of settlement across the landscape appears to have shifted from dispersed and widespread to centralised and concentrated (McNeill and Welch 1991; Welch and McNeill 1991). This marks a shift from localised identity of smaller communities, marked through attachment to specific areas of land and mediated through regional networks, to identity subsumed into a centralised external state.

\section{How can we best explain these changes between conditions?}

This model of integrated social and environmental mutual change and feedback relies more on the fluidity of socio-environmental process than on the primacy of either socio-cultural or environmental process. We are thus able to consider the landscape as a fundamentally socio-environmental construct, in which potentialities emerge, are expressed, and may be influential in changes in social and/or environmental behaviour. This approach is deliberately non-deterministic, in which potentialities may be activated, and in which the most important base condition is that change is only possible where the conception of that action exists. In this way, there may be many possible trajectories - both social and environmental - flowing from any particular set of socio-environmental circumstances, but, importantly, there is no obligation that any of these be necessarily activated. 


\section{The power of a new idea: One of how many possible socio-environmental trajectories?}

To close, and to illustrate the import of this approach, it is useful to consider one such set of possible trajectories. Our example lies at the end of the archaeological sequence described here, when there was an apparent shift in the patterns of landscape occupation and social conditions, changes identified as highly significant by archaeologists (Moore 1988a, b; Higham 1996b, 2002; Welch and McNeil 1991). These have conventionally been explained in terms of a persuasive and inevitable move towards statehood. On the other hand, the apparent abandonment of sites such as Ban Non Wat at the end of the Iron Age could, equally conventionally, be taken simply as evidence of the deterministic effects of environmental degradation. A third possibility, as noted above, is that the sites were not abandoned at all, and that they were simply used in a different way in a more complex landscape that also included larger central sites.

However, in our model, we start with a situation in which the late Iron Age people were presented with, it seems, the need to continue their adaptive use of natural resources, but in a context of deteriorating environmental conditions - deteriorating, that is, relative to the optimal conditions under which the Iron Age people had inherited and maintained their preferred lifestyle. In the event, the social response was to change settlement pattern and, one presumes, the social conditions and structures that may be influenced by or required by this new landscape organisational arrangement. The vegetation was increasingly less able to cope with the cumulative impacts of agriculture and arboriculture, and the engineering responses to maintaining a reliable and predictable water supply were simply not working. Local rainfall patterns were probably also changing, with good evidence that the water in the rivers ceased to be sourced in the upper catchment, and instead relied on localised rainfall.

Fortunately, a new idea was circulating at this time, a notion of an alternative social structure - centralised settlement characteristic of Indianised ideas entering mainland Southeast Asia at the time. This new idea provided an alternative to the concept of settlement extant for several millennia, a concept of dispersed settlement patterns, and a concept that had suited socioenvironmental conditions so far. With a new idea came a new option, thus offering late Iron Age people an alternative social organisation that may have better allowed them to deal with the socio-environmental conditions they now found themselves in. By electing to adopt this option, and thus changing both social organisation and their relationship with the landscape - living in greater numbers and higher concentrations in fewer central towns - society was provided a key possibility that was neither available previously, nor an obligatory pathway into their (then) future.

A valid question still remains. In the absence of the new idea, or, importantly, in a situation where the new idea may not have been taken up, what might have been? Our integrated model of socio-environmental relationship - articulated through and evidenced by the landscape - can provide some suggestions. At an extreme end, a social and population crash and landscape emptying might have been on the cards; such an interpretation is common across the world (cf. Diamond 2005). Alternatively, survival could have relied on one or more of continuing use and adaptation of established technologies and, perhaps, associated social structures within the evolving landscape, or a reordering of the occupation or use of that landscape within the extant social structure. Just because the technologies or social structures that had evolved to date were abandoned at the end of the Iron Age does not mean there is an a priori case that they had become wholly redundant. The experience of human-environment relationships since the Neolithic in this region indicates the resilience and adaptability of both social and environmental conditions within the landscape. Some options may require both the conceptual context for such change, especially if they are stepping outside the received range of possibilities intrinsic in existing technologies and social structures, and the environmental capacity - particular to the history and times of these events - for continued adaptation. 
What consideration of such options reinforces, however, is that the trajectory that was adopted represented a unique combination of socio-environmental circumstances, and that its adoption was only one of many possibilities. By considering this unique change event within its landscape, and thus examining it from the perspective of the detailed interrelationships between people and environment, the roles of memory, continuity, discontinuity and transformation (Rowlands 1993; Schama 1995), and of landscape as identity (Knapp and Ashmore 1999), we have discussed a heuristic able to delve deeply into the social behaviour of past people. By doing this, however, we are forced to move from the detailed description of single sites, to consideration of landscape-scale patterning of human behaviour. This next stage demands that field work and research now be aimed at understanding the broader patterning of individual sites as well as their distributions across the landscape. It also demands that we try to understand the mutual relationships and feedbacks between people and environment, that is, the landscapes that were inherited, occupied, constructed and modified throughout prehistoric time.

\section{Acknowledgements}

The research we discuss here is part of the Origins of the Civilisation of Angkor Project. Our involvement in the research has been funded and supported by grants from a wide range of sources: Marsden Fund (NZ), Australian Research Council (ARC), Australian Institute for Nuclear Science and Technology (AINSE), Earthwatch Institute (USA), National Geographic (USA), Southern Cross University (Australia), James Cook University (Australia), and Cambridge University (Britain). We acknowledge and thank the directors of the Origins of the Civilisation of Angkor Project, Professor Charles Higham, Dr Rachanie Thosarat and Dr Amphan Kijngam, for their invaluable support. We are also grateful to local villagers for their continuing input to the research, and officials of the National Research Council of Thailand, the Royal Thai Fine Arts Department, and the regional Amphoe Non Sung, for permission to conduct this research. The School of Environmental Science and Management at Southern Cross University has allowed access to its extensive array of specialist equipment and support staff. The opinions expressed in this discussion paper are solely those of the authors, and do not necessarily represent those of the Origins of the Civilisation of Angkor Project.

\section{References}

Basso, K.H. 1996. Wisdom sites in places: Notes on a Western Apache landscape. In S. Feld and K.H Basso (eds) Senses of Place, pp53-90. Santa Fe: SAR Press.

Bellina, B. 2003. Beads, social change and interaction between India and South-east India. Antiquity 77:286-297.

Bellwood, P. 2004. The Origins and Dispersals of Agricultural Communities in Southeast Asia. In I. Glover and P. Bellwood (eds) Southeast Asia: from Prehistory to History, pp21-40. Abington: Routledge Curzon.

Bender, B. (ed.) 1993. Landscape: Politics and Perspectives. Oxford: Berg.

Boyd, W.E. 1988. Methodological problems in the analysis of fossil non-artefactual wood assemblages from archaeological sites. Journal of Archaeological Sciences 15:602-619.

Boyd, W.E. 2004. "As fantastic as the Atlantis": Reading a prehistoric floodscape. In: P. Thom (ed.) Flood: Writing across the current, pp65-97. Lismore: Southern Cross University Press. 
Boyd, W.E. 2007. The geoarchaeology of the archaeological sites of Non Muang Kao and Noen U-Loke, Mun River valley, northeast Thailand. In C.F.W. Higham, A. Kijngam and S. Talbot (eds) The Origins of the Civilisation of Angkor Volume 2: The Excavation of Noen U-Loke and Non Muang Kao, pp29-53. Bangkok: The Fine Arts Department of Thailand.

Boyd, W.E. 2008. Social change in late Holocene mainland SE Asia: A response to gradual climate change or a critical climatic event? Quaternary International 184:11-23.

Boyd, W.E., M.M. Cotter, W. O'Connor and D. Sattler 1996a. Cognitive ownership of heritage places: Social construction and the cultural heritage management. Tempus 6:123-140.

Boyd, W.E., M.M. Cotter, J. Gardiner and G. Taylor 2005. Rigidity and a Changing Order. Disorder, Degeneracy and Daemonic Repetition: Fluidity of Cultural Values and Cultural Heritage Management. In T. Darvill, C. Mathers, and B. Little (eds) Heritage of Value, Archaeology of Renown: Reshaping Archaeological Assessment and Significance, pp89-113. Tampa: University Press of Florida.

Boyd, W.E. and J. Habberfield-Short 2007. Geoarchaeological landscape model of the Iron Age settlements of the upper Mun River floodplain. In C.F.W. Higham, A. Kijngam and S. Talbot (eds) The Origins of the Civilisation of Angkor Volume 2: The Excavation of Noen U-Loke and Non Muang Kao, pp1-27. Bangkok: The Fine Arts Department of Thailand.

Boyd, W.E., C.F.W. Higham and R. Thosarat 1996b. The Holocene palaeogeography of the S.E. margin of the Bangkok Plain, Thailand and its archaeological implications. Asian Perspectives 35:139-162.

Boyd, W.E., C.F.W. Higham and R.J. McGrath 1999a. The geoarchaeology of Iron Age "moated" sites of the upper Mae Nam Mun valley, N.E. Thailand. I: Palaeodrainage, sitelandscape relationships and the origins of the "moats". Geoarchaeology: An International Journal 14:675-716.

Boyd, W.E., R.J. McGrath and C.F.W. Higham 1999b. The geoarchaeology of the prehistoric ditched sites of the upper Mae Nam Mun Valley N.E. Thailand, II: Stratigraphy, and morphological sections of the encircling earthworks. Indo-Pacific Prehistory Association Bulletin 18:169-179.

Boyd, W.E. and R.J. McGrath 2001a. The geoarchaeology of the Iron Age ditched sites of the upper Mae Nam Mun valley, N.E. Thailand III: Late Holocene vegetation history. Palaeogeography, Palaeoclimatology, Palaeoecology 171:307-328.

Boyd, W.E. and R.J. McGrath, 2001b. Iron Age vegetation dynamics and human impacts on the vegetation of Upper Mun River floodplain, N.E. Thailand. New Zealand Journal of Geography 57(2):21-32.

Bradley, R. 1997. Rock Art and the Prehistory of Atlantic Europe. London: Routledge.

Butzer, K.W. 1982. Archaeology as human ecology. Cambridge: Cambridge University Press.

Chang 2001 MISSING

Chang, N.J. 1996. Personal ornaments in Thai Prehistory: some preliminary observations from Nong Nor, Central Thailand. Bulletin of the Indo-Pacific Prehistory Association 14:140-150.

Chang, N.J. 2002. Personal ornaments in Thailand: Nong Nor, Ban Luam Khao and Noen U-Loke. Unpublished PhD Thesis. Dunedin: University of Otago.

Chang, N.J. In press. The Shell, Silver, Gold, Bronze and Bone Personal Ornaments. In C.F.W. Higham, A. Kijngam and S. Talbot (eds) The Origins of the Civilisation of Angkor Volume 2: The Excavation of Noen U-Loke and Non Muang Kao. Bangkok: The Fine Arts Department of Thailand.

Chang, N.J. and J. Voelker 2003. Wash and Wear, Disposable and Cheap: Ceramic bangles as everyday personal ornaments not for symbolic use. Bulletin of the Indo-Pacific Prehistory Association 23:19-26. 
Crumley, C.L. 1994. Cultural ecology: a multidimensional ecological orientation. In C.L. Crumley (ed.) Historical Ecology: Cultural Knowledge and Changing Landscapes, pp 1-16. Santa Fe: SAR Press.

Diamond, J. 2005. Collapse: How societies choose to fail or succeed. New York: Viking Books.

Fagan, B. 2007. People of the Earth. Upper Saddle River: Prentice Hall.

Glover, I.C. 1998. The role of India in the late prehistory of Southeast Asia. Journal of Southeast Asian Archaeology 18:21-49.

Glover, I. and P. Bellwood (eds) 2004. Southeast Asia: From Prehistory to History. Avington: Routledge Curzon.

Gould, P. and R. White 1986. Mental maps. London: Allen and Unwin.

Habberfield-Short, J. and W.E. Boyd 2007. The geoarchaeological development of the mounded Iron Age sites of Non Muang Khao and Noen U-Loke, and implications for timing and phasing of the occupation and abandonment of the sites. In C.F.W. Higham, A. Kijngam and S. Talbot (eds), The Origins of the Civilisation of Angkor Volume 2: The Excavation of Noen U-Loke and Non Muang Khao, pp55-73. The Fine Arts Department of Thailand, Bangkok.

Harwood, K. and A.G. Brown 1993. Fluvial processes in a forested anastomosing river: flood partitioning and changing flow patterns. Earth Surface Processes and Landforms 18:741-748.

Head, L., C. Gosden and J.P. White (eds) 1994. Social landscapes. Archaeology in Oceania 29:113-190.

Higham, C.F.W. 1977. The prehistory of the Southern Khorat Plateau, with particular reference to Roi Et Province. Modern Quaternary Research in Southeast Asia 3:103-142.

Higham, C.F.W. 1996a. The Bronze Age of Southeast Asia. Cambridge: Cambridge University Press.

Higham, C.F.W. 1996b. A review of archaeology in Mainland Southeast Asia. Journal of Archaeological Research 4:3-49.

Higham, C.F.W. 2000. The Origins of the Civilisation of Angkor: the final report to the National Research Council of Thailand. Dunedin: Department of Anthropology, University Of Otago.

Higham, C. 2002. Early cultures of Mainland Southeast Asia. Bangkok: River Books.

Higham, C. 2004. Ban Non Wat: Lessons from the field. In V. Paz (ed.) Southeast Asian Archaeology: Wilhelm G. Solheim II Festschrift, pp491-503. Manilla: University of the Philippines Press.

Higham, C.F.W. and A. Kijngam 1982. Irregular earthworks in N.E. Thailand: new insight. Antiquity 56:102-110.

Higham, C.F.W. and T.L.-D. Lu 1998. The origins and dispersal of rice cultivation. Antiquity 72:867-877.

Higham, C.F.W. and R. Thosarat 1998. Prehistoric Thailand: From Early Settlement to Sukhothai. Bangkok: River Books.

Higham, C.F.W. and R. Thosarat 2005. The Origins of the Civilisation of Angkor: Volume 1: The excavation of Ban Lum Khao. Bangkok: The Fine Arts Department of Thailand.

Higham, C.F.W., A. Kijngam and S. Talbot 2007. The Origins of the Civilisation of Angkor Volume 2: The Excavation of Noen U-Loke and Non Muang Kao. Bangkok: The Fine Arts Department of Thailand.

Källén, A. 2004. And Through Flows the River: Archaeology and the Pasts of Lao Pako. Upsalla: Studies in Global Archaeology, 6.

Knapp, A.B. and W. Ashmore 1999. Archaeological Landscapes; constructed, conceptualised, ideational. In W. Ashmore and A.B. Knapp (eds) Archaeology of Landscape: Contemporary Perspectives, pp 1-30. London: Blackwell.

Lasca, N.P. and J. Donahue (eds) 1990. Archaeological Geology of North America. Boulder: The Geological Society of America. 
Maxwell, A.L. 2001. Holocene monsoon changes inferred from lakes sediment pollen and carbonate records, northeastern Cambodia. Quaternary Research 56:390-400.

Maxwell, A.L. and K.-B. Liu 2002. Late Quaternary pollen and associated records from the monsoonal areas of continental South and SE Asia. In P. Kershaw, B. David, N. Rapper, D. Penny and J. Brown (eds). Bridging Wallace's Line: The environmental and cultural history and dynamics of the SE-Asian-Australian Region, pp189-228. Reiskirchen: Catena Verlag.

McGrath, R.J., W.E. Boyd and R.T. Bush 2008. The paleohydrological context of the Iron Age floodplain sites of the Mun River valley, Northeast Thailand. Geoarchaeology: An International Journal 23:151-172.

McGrath, R.J. and W.E. Boyd 2001. The chronology of the Iron Age 'moats' of northeast Thailand. Antiquity 75:349-360.

McNeill, J.R. and D.J. Welch 1991. Regional and interregional interaction on the Khorat Plateau. Bulletin of the Indo-Pacific Prehistory Association 10:327-340.

Moore, E.H. 1988a. Moated Sites in Early North East Thailand. Oxford: BAR International Series 400, British Archaeological Reports.

Moore, E.H., 1988b. Notes on two types of moated settlements in North East Thailand. Journal of the Siam Society 76:275-287.

Moore, E.H. 1992. Water-enclosed sites: Links between Ban Takhong, northeast Thailand and Cambodia. In J. Rigg (ed.) The gift of water: Water Management, cosmology and the State of South East Asia, pp22-25. London: School of Oriental and African Studies.

Mudar, K.M. and V.C. Pigott 2003. Subsistence changes and community based craft production in prehistoric Central Thailand. In A. Karlstrom and A. Kallen (eds) Fishbones and Glittering Emblems: Southeast Asian Archaeology 2002. pp149-160. Stockholm: Museum of Far Eastern Antiquities.

Nitta, E. 1991. Archaeological study on the ancient iron-smelting and salt-making industries in the northeast of Thailand: Preliminary report on the excavations of Non Yang and Ban Don Phlong. Journal of Southeast Asian Archaeology 11:1-46.

O'Reilly, D.J.W. 1998. The discovery of clay-lined floors at an Iron Age Site in Thailand; Preliminary observations from Non Muang Kao, Nakhon Ratchasima Province. Journal of the Siam Society 85:1-14.

O'Reilly, D.J. 1999. A diachronic analysis of social organisation in the Mun River Valley. Unpublished PhD Thesis. Dunedin: University of Otago.

O'Reilly, D.J.W. 2000. From the Bronze Age to the Iron Age in Thailand: Applying the heterarchical approach. Asian Perspectives 39:1-19.

O'Reilly, D.J.W. 2003. Further evidence of heterarchy in Bronze Age Thailand. Current Anthropology 44:300-306.

O'Reilly, D.J.W. 2007. Early Civilizations of Southeast Asia. New York: Alta Mira Press.

O'Reilly, D.J.W. and P. Sytha 2001. Recent excavations in northwest Cambodia. Antiquity 75:265-266.

Rapp, G. Jr. and J.A. Gifford (eds) 1986. Archaeological Geology. New Haven: Yale University Press.

Rapp, G. Jr. and C.L. Hill 1998. Geoarchaeology: The Earth Science Approach to Archaeological Interpretation. New Haven: Yale University Press.

Ross, A. 1996. Landscape as heritage. Tempus 5:1-17.

Rowlands, M. 1993. The role of memory in the transmission of culture. World Archaeology 25:141-151.

Schama, S. 1995. Landscape and Memory. London: Harper Collins.

Stark, M. (ed.) 2006. Archaeology of Asia. Malden: Blackwell.

Talbot, S. 2000. Notes from the field: an excavation at a Khmer Temple in Northeast Thailand. New Zealand Journal of Asian Studies 11:162-168. 
Talbot, S. 2002. From the Iron Age to Angkor in Northeast Thailand. Unpublished Ph.D. Thesis. Dunedin: University of Otago.

Theunissen, R. 2003. Agate and Carnelian Beads and the Dynamics of Social Complexity in Iron Age Mainland Southeast Asia. Unpublished PhD Dissertation. Armidale: University of New England.

Tilley, C. 1994. A Phenomenology of Landscape: Places, Paths and Monuments. Oxford: Berg.

Tuan, Y.-F. 1974. Topophilia: a study of environmental perception, attitudes, and values. New York: Columbia University Press.

Tuan, Y.-F. 1977. Space and place: the perspective of experience. London: Edward Arnold.

Waters, M.R. 1996. Principles of Geoarchaeology: A North American Perspective. Tuscon: University of Arizona Press.

Welch, D. 1984. Settlement patterns as an indicator of sociopolitical complexity in the Phimai region. In D.T. Bayard (ed.). Southeastern Asian Archaeology at the XV Pacific Science Congress, pp129-151. Dunedin: Otago University Studies in Prehistoric Anthropology 16.

Welch, D.J. and J.R. McNeill 1991. Settlement, agriculture and population changes in the Phimai region, Thailand. Bulletin of the Indo-Pacific Prehistory Association 11:210-228.

White, J.C. 1995. Incorporating heterarchy into theory on socio-political development: the case from Southeast Asia. In R. Ehrenreich, C. Crumley and J. Levy (eds) Heterarchy and the Analysis of Complex Societies: Comments. pp102-123. Washington DC: American Anthropological Association.

Williams-Hunt, P.D.R. 1950. Irregular earthworks in Eastern Siam: An air survey. Antiquity 24:30-37. 